\title{
RTF GLOVEBOX STRIPPER REGENERATION DEVELOPMENT (U)
}

by A. K. Birchenall

Westinghouse Savannah River Company Savannah River Site

Aiken, South Carolina 29808

Other Authors:
WSRC-RP- $-92-530$

DE93 008507

This paper was prepared in connection with work done under Contract No. DE-AC09-89SR18035 with the U. S. Department of Energy. By acceptance of this paper, the publisher and/or recipient acknowledges the U.S. Government's right to retain a nonexclusive, royalty-free license in and to any copyright covering this paper, along with the righi io reproduce and to authorize others to reproduce all or part of the copyrighted paper.

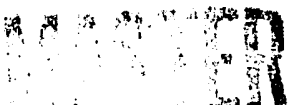




\section{DISCLAIMER}

This report was prepared as an account of work sponsored by an agency of the United States Government. Neither the United States Government nor any agency thereof, nor any of their employees, makes any warranty, express or implied, or assumes any legal liability or responsibility for the accuracy, completeness, or usefulness of any information, apparatus, product, or process disclosed, or represents that its use would not infringe privately owned rights. Reference herein to any specific commercial product, process, or service by trade name, trademark, manufacturer, or otherwise does not necessarily constitute or imply its endorsement, recommendation, or favoring by the United States Government or any agency thereof. The views and opinions of authors expressed herein do not necessarily state or reflect those of the United States Government or any agency thereof.

This report has been reproduced directly from the best available copy.

Available to DOE and DOE contractors from the Office of Scientific and Technical Information, P. O. Box 62, Oak Ridge, TN 37831; prices available from (615) $576-8401$.

Available to the public from the National Technical Information Service, U. S. Department of Commerce, 5285 Port Royal Rd., Springfield, VA 22161. 
WSRC-TR-92-530

October 31, 1992

TO:

T. MOTYKA

FROM: A. K. BIRCHENALL

\section{RTF GLOVEBOX STRIPPER REGENERATION DEVELOPMENT}

\section{Introduction}

Currently, the Replacement Tritium Facility (RTF) glovebox stripper system consists of a catalytic oxidation front end where trace tritium which may escape from the primary tritium process into the glovebox nitrogen system is oxidized to tritiated water. The tritiated water, along with normal water which may leak into the glovebox from the surrounding atmosphere, is then captured on a zeolite bed. Eventually, the zeolite bed becomes saturated with water and must be regenerated to remain effective as a stripper. This is accomplished by heating the zeolite and evolving the trapped water which is then passed over an elevated temperature uranium bed. The uranium bed oxidizes, cracking the water released from the zeolite bed. The oxygen from the water is retained on the uranium bed and the resulting hydrogen isotope mixture is sent to cryogenic distillation for isotope separation. The tritium rich product is returned to the primary tritium process. The problem with this arrangement is that the uranium bed is consumed in the process and cannot be regenerated since the temperatures necessary to decompose the stable uranium oxide would result in a sintered uranium product with greatly reduced surface area for subsequent water cracking. Therefore, each uranium bed is disposed of in an approved above-ground repository after use. Regulations governing future disposal of uranium waste have been tightened, driving up the cost of future uranium disposal. Additionally, sacrificial uranium beds imply routine entrance into the primary process to remove the beds. This implies additional routine down time, risk of personnel contamination and potential for environmental releases. Alternative technologies are therefore sought to crack tritiated water without the use of sacrificial uranium beds.

A waste minimization program was instituted to address this issue. The program has two parallel paths. One path investigates replacing the entire glovebox stripper system with a system of getters to scavenge trace tritium. This report concentrates on the second path, retaining the catalytic oxidation front end but replacing the uranium bed water cracking with alternative technologies. 
T. MOTYKA

WSRC-TR-92-530

Page 2

October 31, 1992

Three main groups of technologies were identified to replace uranium bed cracking of tritiated water. These include electrolysis in which water is decomposed into its constituents in an electrochemical cell, isotope exchange where the tritiated water is passed over a catalyst bed while contacted with hydrogen gas, and substitution of alternative sacrificial metal beds for uranium. The preferred technology selected for further study is solid oxide electrolysis. Solid polymer electrolysis has also been investigated. Because of funding limitations, both technologies cannot be aggressively pursued simultaneously. Solid polymer electrolysis will be held in reserve should significant problems develop with solid oxide electrolysis.

\section{Electrolysis}

In electrolysis, a current is passed between two electrodes. The substance to be decomposed, in this case tritium-bearing water, is supplied to one electrode. At that electrode, an electrochemical reaction occurs where one of the constituents of the substance is evolved. The electrode is in contact with another material which is selected to transport ions. This material is known as an electrolyte. For the variety of electrolysis cells available to decompose tritiated water, the type of electrolyte employed serves as a convenient means of classification. Ions of one of the consituents of the substance being decomposed are transported through the electrolyte to the second electrode where they may recombine into molecules.

\section{Solid Oxide Electrolysis}

The first electrolysis cell considered uses a solid oxide electrolyte, yttria-stabilized zirconia. Zirconium oxide is an oxygen ion conductor. Yttria is added to suppress an undesirable phase transformation which would otherwise lead to cracking of the electrolyte. To obtain reasonable kinetics because of the low mobility of oxygen ions in the zirconia lattice, the electrolyte must be operated at elevated temperatures, 700$1000^{\circ} \mathrm{C}$. Water vapor is supplied to the cathode of the cell where it adsorbs and cracks into constituent hydrogen and oxygen. The hydrogen recombines at the cathode and is evolved as molecular hydrogen gas. Oxygen is transported through the electrolyte to the anode where it recombines and is evolved as molecular oxygen gas. It is undesirable to maintain substantial quantities of oxygen gas in a tritium facility. Thus the resulting oxygen from the electrolysis cell should be stacked as soon as possible as long as the tritium content of the oxygen is low enough that it does not lead to appreciable stack releases. The solid oxide electrolyte cell is optimum for this purpose since the permeability of hydrogen and water, hence tritium, through the solid oxide electrolyte is very low. Thus the tritium content of the oxygen should render it immediately stackable. 
T. MOTYKA

WSRC-TR-92-530

Page 3

October 31, 1992

Two potential vendors were identified for solid oxide electrolyte electrolysis cells. Mitsubishi Corporation in conjunction with the Japan Atomic Energy Research Institute (JAERI) has been conducting tesis of such a cell at the Tritium System Test Assembly, located at Los Alamos National Laboratory, in support of fusion technology1,2. Their cell is shown in Figure 1. Multiple closed-end tubes of the zirconia electrolyte are mounted in a shell and supplied by a manifold. The water vapor is fed to the platinum paste electrode on the inside of the tubes where it decomposes into hydrogen. Since all the water vapor does not decompose immediately, it is necessary to recirculate the water vapor-bearing gas stream through the inside of the tubes until a low water vapor content is achieved. Water vapor in the exit hydrogen stream could clog the cryogenic distillation column used in subsequent separation of the hydrogen isotopes. Oxygen is transported through the tubes to the platinum paste electrode on the outside of the tube where molecular oxygen is produced. The oxygen is stored in a tank until it is analyzed for release to the atmosphere. In the absence of cracks in the tubes, the tritium and tritiated water content of the oxygen should be very low.

A problem with the Mitsubishi system has been observed in the test program at Los Alamos. This relates to the joints between the zirconia tubes and the stainless steel manifold. Mitsubishi used a diffusion joint where titanium is deposited between the metal and ceramic and diffused into both to form a coupling. These joints have been cracking rapidiy in the Los Alamos tests. Analysis of failed joints show zones of brittle fracture on both the inside and outside of the joint with a ductile region of fracture in the middle of the tube cross section. The titanium is exposed to oxygen on the outside of the tube and hydrogen on the inside of the iube. Titanium is highly reactive with both gasses.

An alternative vendor to Mitsubishi was located. The solid oxide electrolysis cell is very similar in design to high temperature fuel cells. A fuel cell electrochemically reacts fuel and oxidant to form a thermodynamically stable reaction product while producing electrical energy. An electrolysis cell consumes electrical energy to decompose a thermodynamically stable species into its components. The Westinghouse Electric Company is a world leader in solid oxide fuel cell technology. They were approached with this problem. The small size of the program, one or two units, was not sufficient to interest the Westinghouse fuel cell manufacturing division. However, they referred us to their research and support group at the Westinghouse Science and Technology Center $3,4,5$. The Science and Technology Center had performed a similar project for the National Aeronautics and Space Administration 6 . This program had been discontinued by NASA and much of the equipment used in this effort was on hand at the Science and Technology Center or retrievable from NASA. This experience and the availability of this equipment 
T. MOTYKA

WSRC-TR-92-530

Page 4

October 31, 1992

would significantly reduce the projected expense and duration of a development program.

While the Westinghouse electrolysis unit is similar to that of Mitsubishi in that it consists of multiple closed-end tubes of yttria-stabilized zirconia mounted in a stainless steel shell, there are several differences. Figure 2 shows a cross section of a Westinghouse electrolysis tube. The inner portion of the tube is a porous tube of yttria-stabilized zirconia. This is, however, not the electrolyte and is used merely for support of the subsequent elements of the tube. The next element is the anode which is a layer of conductive oxide deposited on the inner tube. In contrast to the Mitsubishi design, Westinghouse puts the anode on the inside of the tubes. The water vapor is supplied to the outside of the tubes, in the shell, and the oxygen is drawn off from the inside of the tubes through the manifold. A conductive oxide is used as the anode since it will not degrade in the oxygen atmosphere, potentially reducing the cell performance over time.

The next element of the tube is the yttria-stabilized zirconia electrolyte which is deposited over the anode. During deposition, a region of the tube circumference is masked off to accommodate electrical connection to the anode. This connection is made by means of nickel felt. Next, the cathode is deposited over the electrolyte. The cathode material was selected to be a nickel-based cermet material because of its catalytic properties. Again, the region of the tube circumference around the electrical connection to the anode is masked during deposition to avoid short circuiting the electrolyte.

Traditionally, Westinghouse has joined the ceramic tubes to the stainless steel manifold by means of epoxy in its commercially supplied fuel cells. This design has worked well in service. However, organic substances such as epoxy are known to degrade rapidly under tritium exposure. Westinghouse was therefore requested to include alternate tube-to-manifold joining methods in their proposed program. They anticipate using a glass-to-metal graded seal.

The proposed Westinghouse Science and Technology Center program begins with evaluation of several types of metal-to-ceramic joints. The superior joint technology will then be tested in a cell using a single ceramic tube. If these tests are successful, a multiple tube cell, sized to fulfill the Replacement Tritium Facility needs will be designed, fabricated and subjected to long terin tests using non-tritiated water at the Science and Technology Center. Upon successful completion of these tests, the multiple tube unit will be shipped to SRS for testing using tritiated water in the Material Test Facility. 
T. MOTYKA

WSRC-TR-92-530

Page 5

October 31, 1992

\section{Solid Polymer Electrolysis}

Other types of electrolysis cells use different types of electrolytes. Another appropriate cell uses a solid polymer electrolyte 7 . This material is a Dupont NAFION membrane which is a sulfonated fluoropolymer similar to teflon. The membrane is a hydrogen ion conductor. Water vapor is supplied to the anode which is a proprietary, waterresistant platinum structure deposited on the membrane. Hydrogen is transported through the membrane to the cathode which is the same material as the anode. Molecular hydrogen gas evolves at the cathode while molecular oxygen is formed at the anode. One disadvantage of this cell design is that the membrane is permeable to water vapor. Thus tritiated water vapor may be present in both the exit hydrogen isotope and oxygen exhaust streams. This requires that scrubbers be routinely employed in a system based on solid polymer electrolysis.

The potential vendor for solid polymer electrolysis is the Hamilton Standard Division of the United Technologies Corporation. The main application of their electrolysis is in oxygen generation from sea water for use in American and British submarines. Additionally, cells supplied by Hamilton Standard have been used by Mound Laboratory, Miamisburg, Ohio, in a system called Combined Electrolysis Catalytic Exchange. In this system, a solid polymer electrolysis cell provides the hydrogen gas stream fed to an isotope exchange column. The normal lifetime of a solid polymer membrane in non-tritiated water electrolysis is in excess of ten years. Mound Laboratory has found that damage from the tritium beta radiation reduces this lifetime to around two years. This is still a substantial lifetime and this observation is consistent with favorable SRS experience with the similar material teflon in tritium service as valve packings. The solid polymer electrolysis cell does offer the advantage that it reduces the inventory of tritium-bearing fluid when compared to systems using aqueous phase electrolytes. A quote for budget purposes has been obtained from Hamilton Standard for a system incorporating a solid polymer electrolysis cell. The system also includes scrubbers to remove water vapor from the exhaust and product gas streams.

There is not currently available funding to pursue both solid polymer and solid oxide electrolysis. Solid oxide cells will be thoroughly investigated first for this application. The information in the quote on solid polymer electrolysis will be held in reserve in case an insurmountable problem arises with the initial solid oxide electrolysis investigations. 
T. MOTYKA

WSRC-TR-92-530

Page 6

October 31, 1992

\section{Aqueous Electrolyte Cells}

A third type of electrolysis cell uses an aqueous potassium hydroxide electrolyte. An aqueous solution of potassium hydroxide has an anode and cathode immersed in it. The drawbacks with this system is that tritium concentrates in the electrolyte, eventually producing a waste that is more difficult to dispose of than the original tritiated water. As with solid polymer electrolysis, water vapor bearing tritium contaminates both the hydrogen and the oxygen gas streams. Unlike solid polymer electrolysis, potassium hydroxide electrolysis requires the maintenance of a large inventory of tritiated aqueous phase in the cell. Additionally, such cell have a reputation for leakage of what in this case would be tritiated water vapor. Since such a cell would presumably be located in the RTF glovebox, this would amount of reintroduction of tritiated water into the glovebox from the stripper regeneration system. Since this approach exhibited so many drawbacks when compared to solid oxide and solid polymer electrolysis, no vendor for this technique was identified and no further effort in this area is anticipated.

\section{Isotope Exchange}

Isotope exchange refers to the transfer of tritium from either a molecular gas phase to a water vapor or aqueous phase or from water to a molecular gas phase. These exchange reactions occur on catalysts. Two major technologies and a third combination of technologies are available for detritiation using this approach. They are vapor phase catalytic exchange, aqueous phase catalytic exchange, and combined electrolysis-catalytic exchange. In general, these techniques are appropriate for detritiation of larger volumes of slightly contaminated water. In RTF glovebox stripper regeneration, only small amounts of moderately contaminated water are involved. Isotope Exchange was researched in this study only for completeness, even though numerous applications of these technologies may be found at SRS and throughout the DOE Weapons Complex.

\section{Vapor Phase Catalytic Exchange}

The first type of isotope exchange technology is called vapor phase catalytic exchange $8,9,10$. A detritiation plant based on this technology has been built at Darlington by Ontario Hydro for removal of tritium from the moderator of CANDU reactors. As in SRS reactors, CANDU reactors are heavy water moderated and develop a tritium concentration in the heavy water through neutron capture by deuterium. Vapor phase catalytic exchange was selected as the technology for a proposed moderator detritiation plant for SRS reactors. This SRS project has since been canceled. In vapor phase catalytic exchange, the input tritiated water is 


\section{T. MOTYKA}

WSRC-TR-92-530

Page 7

October 31, 1992

vaporized and supplied to a catalyst. A supply of non-tritiated molecular hydrogen gas is also supplied to the platinum catalyst. The concentrations of the water vapor and molecular hydrogen are selected such as to promote transfer of tritium from the water to the molecular hydrogen phase on the catalyst. The output hydrogen gas stream would then be sent to an isotope separation process such as cryogenic distillation to remove the low concentration tritium-containing molecules from the predominantly protium stream. The reactor moderator is usually at about a two order of magnitude lower tritium concentration than the water considered in the RTF glovebox stripper system.

Multiple columns are used to facilitate isotope exchange. Each column requires an evaporator at the bottom to vaporize the water and a condenser at the top of the column. This equipment greatly adds to the capital and operating costs of the process.

\section{Aqueous Phase Isotope Exchange}

A second type of isotope exchange process simplifies the capital equipment required. This process is aqueous phase isotope exchange $11,12,13$. In this process, the tritiated water is supplied to the catalyst as a liquid, thus eliminating the otherwise required evaporators and condensers. The problem with this technology is that liquid water tends to cover the catalyst and preclude the access of the exchangeable molecular hydrogen to the active sites on the catalyst surface. This problem has been overcome in an approach pioneered by Atomic Energy of Canada, Limited, (AECL) also in support of detritiation of CANDU reactor moderator. In AECL's approach, teflon is used as a hydrophobic catalyst support. Water does not wet the teflon. Thus it does not spread out to cover the separate metal particles of catalyst. Water vapor from water drops is, however, available to supply the catalyst surface with reactant. As in vapor phase catalytic exchange, tritium may transfer from the aqueous phase to the molecular hydrogen gas phase via the catalyst. AECL had planned to construct a pilot plant based on this technology but apparently these plans have been delayed. The reason for this delay is not known, but the lifetime of the catalyst in tritium service is not known nor is there any industrial scale experience with this catalyst as yet.

The availability of this catalyst to the DOE Weapons Complex is also questionable. Canadian national policy prohibits sale of this technology on a non-proliferation basis. This prohibition extends to the United States. Small samples have been made available for testing to various DOE organizations. However, a potential second source of similar catalyst has been discovered. The Hamilton Standard Division of the United Technologies Corporation sells a very similar aqueous phase catalyst for oxidation of volatile organic compounds as impurities in aqueous systems. Their prime market is clean up of waste streams in closed environment systems such as 
submarines and the Space Shuttle. The catalyst is platinum supported on teflon as is the AECL catalyst. It should be effective in isotope exchange. To test the Hamilton Standard catalyst for its isotope exchange performance, the material has been included in a program to separate deuterium from tap water in an experiment to be carried out by the Chemical Engineering Department of the University of South Carolina under contract to the Waster and Environmental Restoration Program of the Savannah River Technology Center. Should these tests be successful, there are a wide range of potential applications for such a catalyst in the DOE Weapons Complex. At Savannah River, there are tritium containing seepage basins, reactor moderator and Effluent Treatment Facility output. Los Alamos National Laboratory, Mound Laboratory, and Hanford also have supplies of tritium-contaminated aqueous wastes.

\section{Combined Electrolysis - Catalytic Exchange}

The third isotope exchange-related technology is really a combination of isotope exchange coupled with electrolysis. This is Combined Electrolysis -Catalytic Exchange $(\mathrm{CECE})^{14}$. CECE is very similar to aqueous phase catalytic exchange except the molecular hydrogen strearn to the aqueous phase catalyst is supplied by an electrolysis cell and the catalyst column is sized to favor tritium transfer from the gas phase to the aqueous phase.

CECE was pioneered by Mound laboratory in the DOE Weapons Complex. Mound chose to use a solid polymer electrolyte electrnlysis cell in their system. The system is shown schematically in Figure 3. The tritiated water feed enters the center of a two section column of aqueous phase catalyst. The lower catalyst section enriches the tritiated water with tritium from the electrolysis cell. The enriched water passes on down the column to the electrolysis unit where it is decomposed to form the molecular gas stream sent up the column. A side stream of tritium-bearing gas from the electrolysis cell is sent for cryogenic distillation. The upper catalyst section is fed with pure water and is used to strip tritium from the molecular gas stream prior to release of the gas. This technique again requires the special hydrophobic catalyst which may not be available and also requires a large electrolysis unit. However, since tritium tends to concentrate in the electrolysis unit, the demand on throughput to the cryogenic still is reduced.

\section{Alternative Hot Metal Beds}

A third approach to the elimination of uranium beds is to substitute another metal in place of uranium. This approach is not optimum in that it still results in burial of a tritium-exposed waste, albeit not uranium, and it requires routine line breaks in the system to facilitate removal of the consumed metal bed. 
Magnesium beds are already used in the tritium facility. They are not considered desirable since the oxidation kinetics in water exhibit a passivation behavior (the rate of oxidation decreases drastically as oxidation progresses). On the other hand, Los Alamos, in the Tritium Systems Test Assembly, has had favorable recent experience with magnesium and they prefer it to urarium for decomposition of tritiated water.

A key element in selection of an appropriate consumable hot metal bed is the oxidation kinetics of the metal in water vapor. Metals develop a scale of oxidation product on their surfaces during oxidation. The rate of the continuing reaction depends on mass transport through the increasingly thick oxide scale. Since the mass transport distances through the scale become larger as oxidation, and hence scale thickness, progresses, the rate of the oxidation reaction decreases with time and the mass change of a sample, when plotted against time, exhibits a parabolic form. The derivative of this plot is the reaction rate and this tends toward zero as the reactions progresses. In some cases, the oxide scale will not remain dense or adherent to the metal surface. Then, rapid, gas phase transport of the reactant to the metal interface may occur and the plot of mass change versus time shows a linear dependence (no passivation). In the case of a sacrificial bed, linear oxidation kinetics are desirable in order to have rapid decomposition of the reactant and to minimize the amount of metal to be disposed of. Titanium is known to exhibit linear oxidation kinetics in water vapor above $800^{\circ} \mathrm{C}^{15}$. As such, it would be a appropriate candidate material for uranium substitution. Titanium, like uranium, forms a stable metal hydride. However, like uranium, the operating temperature of the hot metal bed would be above the decomposition temperature of the hydride. Studies continue to identify appropriate candidate substitute materials. A number of commercial oxygen getter materials, mainly zirconium-based materials, are available and would probably be appropriate for this application. Unfortunately, these materials are very expensive, in the range of $\$ 400-\$ 1000$ per kilogram. This seems much too high for a sacrificial application involving hundreds of kilograms of material.

\section{Conclusions}

The preferred technology for uranium bed replacement in the RTF glovebox stripper regeneration facility is solid oxide electrolysis. Its chief advantage over solid polymer electrolysis is that water vapor does not permeate through the electrolyte such that routine use of scrubbers to remove tritium-bearing water vapor from the exhaust oxygen stream is not required. The preferred vendor for solid oxide electrolysis is the Westinghouse Science and Technology Center due to their extensive experience with solid oxide fuel cells and their completion of a similar solid oxide electrolysis cell for NASA. While there is not currently available funding to pursue solid polymer 
electrolysis in parallel with the solid oxide cell, a vendor has been identified and a preliminary cost estimate has been obtained as a second approach, should insurmountable problems arise with solid oxide electrolysis.

Catalytic exchange was also investigated. These techniques are more suited for larger volumes of lower tritium content. A second source, not encompassed by Canadian export restrictions, for aqueous phase isotope exchange catalyst was identified. While it is not planned to pursue this technique in this program, there are numerous potential applications throughout the DOE Weapons Complex that are under active investigation. The second source of catalyst was brought to the attention of investigators at both Savannah River and Hanford.

While substitution of alternative metals for uranium as a hot metal bed suffers from the drawbacks that it still requires disposal of tritium-exposed waste and further requires routine line breaks into the tritium-containing system, a candidate material was identified. Further literature study of oxidation behavior of other metals in water vapor is continuing.

\section{References}

1. S. Konishi, H. Ohno, H. Yoshida, anci Y. Naruse, "Decomposition of Tritiated Water with Solid Oxide Electrolysis Cell","Nucl. Technol./Fusion, 3, 195 (1983).

2. S. Konishi, H. Yoshida, H. Ohno, Y. Naruse, D. Coffin, C. R. Walthers and K. Binning, "Experiments on a Ceramic Electrolysis Cell and a Palladium Diffuser at the Tritium Systems Test Assembly", Fusion Technology, 8, 2042-2394, Sept. 1985.

3. N. J. Maskalick and D. Zuckerbrod, "High Temperature Steam ElectrolysisTheory and Verification" Westinghouse R\&D Center Report 84-9D12-WESOC-P2, (1984).

4. N. J. Maskalick, "Anodic Overpotential in High-Temperature Steam Electrolysis", Westinghouse R\&D Center Report 86-9V11-WESOC-P1， (1986).

5. N. J. Maskalick and D. K. McLain, "Performance Modles for Zirconia Electrolyte Cells at Low Current Density", Journal of the Electrochemical Society, Vol. 135, No. 1, (1988). 
T. MOTYKA

WSRC-TR-92-530

Page 11

October 31, 1992

6. A. O. Isenberg and C. E. Verostko, "Carbon Dioxide and Water Vapor High Temperature Eiectrolysis", 19th Intersociety Conference on Environmental Systems, Society of Automotive Engineers, San. Diego, CA, July, 1989.

7. M. W. Verbrugge, R. F. Hill and E. 'W. Schneider, "Composite Membranes for Fuel Cell Applications", AIChE Journal, Vol. 38, No. 1, pp. 93, 1992.

8. P. K. Baumgarten, "Technical Data Summary - Moderator Detriation Plant - Sulzer Process", DPSTD-83-84, duPont Report, Savannah River Laboratory, Aiken SC, (1983).

P. Pautrot and M. Damiani, "Operating Experience with the Tritium and Fydrogen Extraction Plant at the Laue-Langevin Institute", pp. 163-170 in Separation of Hydrogen Isotopes, F. K. Rae ed., ACS Symposium Series 68, American Chemical Society, (1978).

10. R. B. Davidson, P. Von Hatten, M. Schaub and D. Ulrich, "Commissioning and First Operating Experience at Darlington Tritium Removal Facility", Fusion Technology, Vol. 14, No. 2, pp. 472, Toronto (1988).

11. J. T. Enright and T. T. Chuang, "Deuterium Exchange Between Hydrogen and Water in a Trickle Bed Reactor", The Canadian J. of Chem. Eng., vol. 56, pp246-250, (1978).

12. R. J. Quaiattini, M. P. McGauley and D. L. Burns, "Conversion of Deuterium Gas to Heavy Water by Catalytic Isotopic Exchange Using Wetproof Catalyst", Nuclear Technology, Vol. 77, pp. 295-298, (1987).

13. W. J. Holtslander, T. E. Harrison, and J. D. Gallagher, "The Chalk River Tritium Extraction Plant Construction and Early Commissioning", Fusion Technology, Vol. 14, pp. 484-488, (1988).

14. D. A. Spagnolo, A. E. Everatt, P.W. K. Seto and K. T. Chuang, "Enrichment and Volume Reduction of Tritiated Water Using Combined Electrolysis Catalytic Exchange", Fusion Technology, Vol. 14, pp. 501-506, (1988).

15. S. Mrowec and T. Werber, Gas Corrosion of Metals, Foreign Scientific Publications, Department of the National Center for Scientific, Technical and Economic Information, Warsaw, pp. 427, (1978).

Atts. (3) 


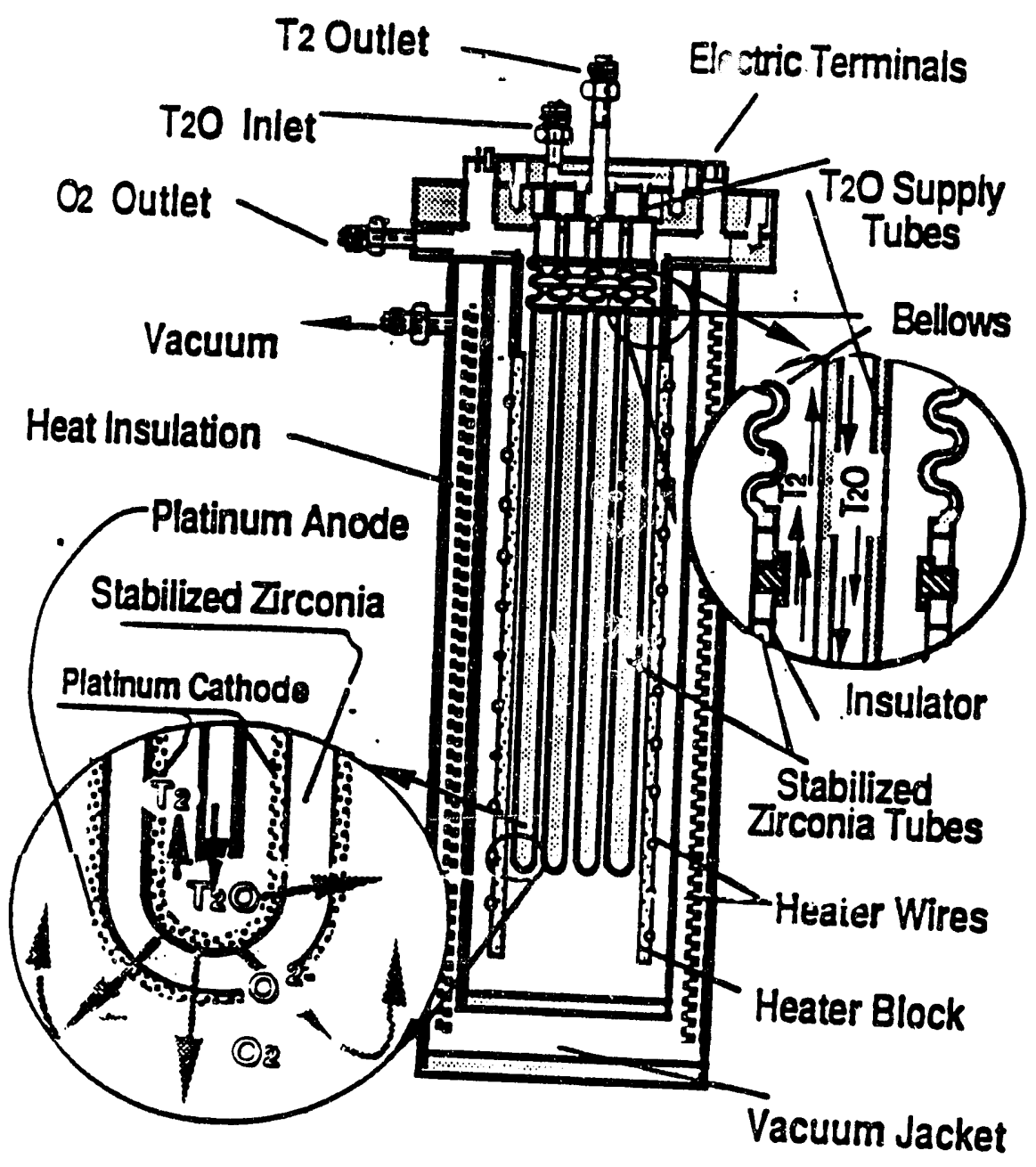

Figure 1 


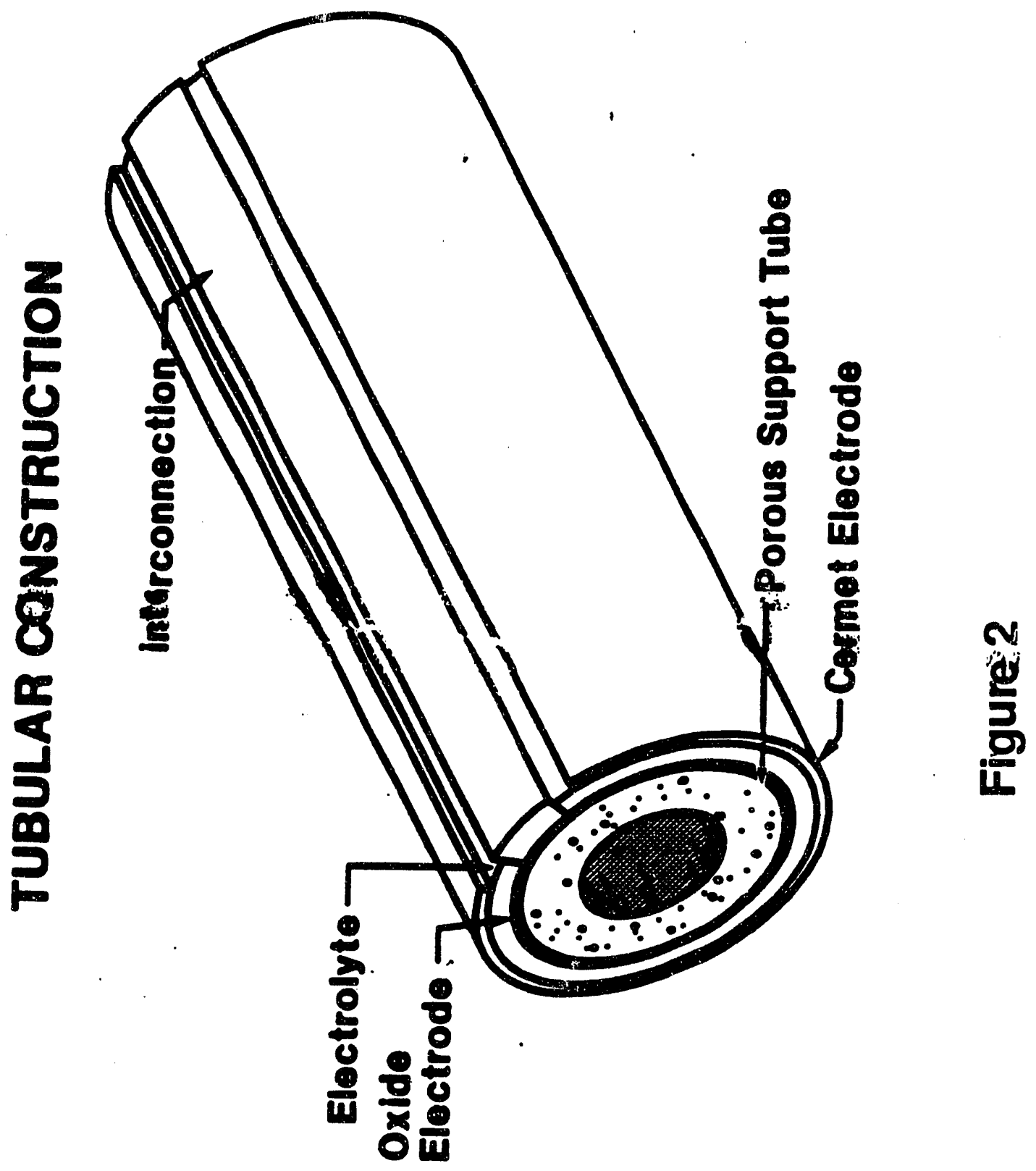




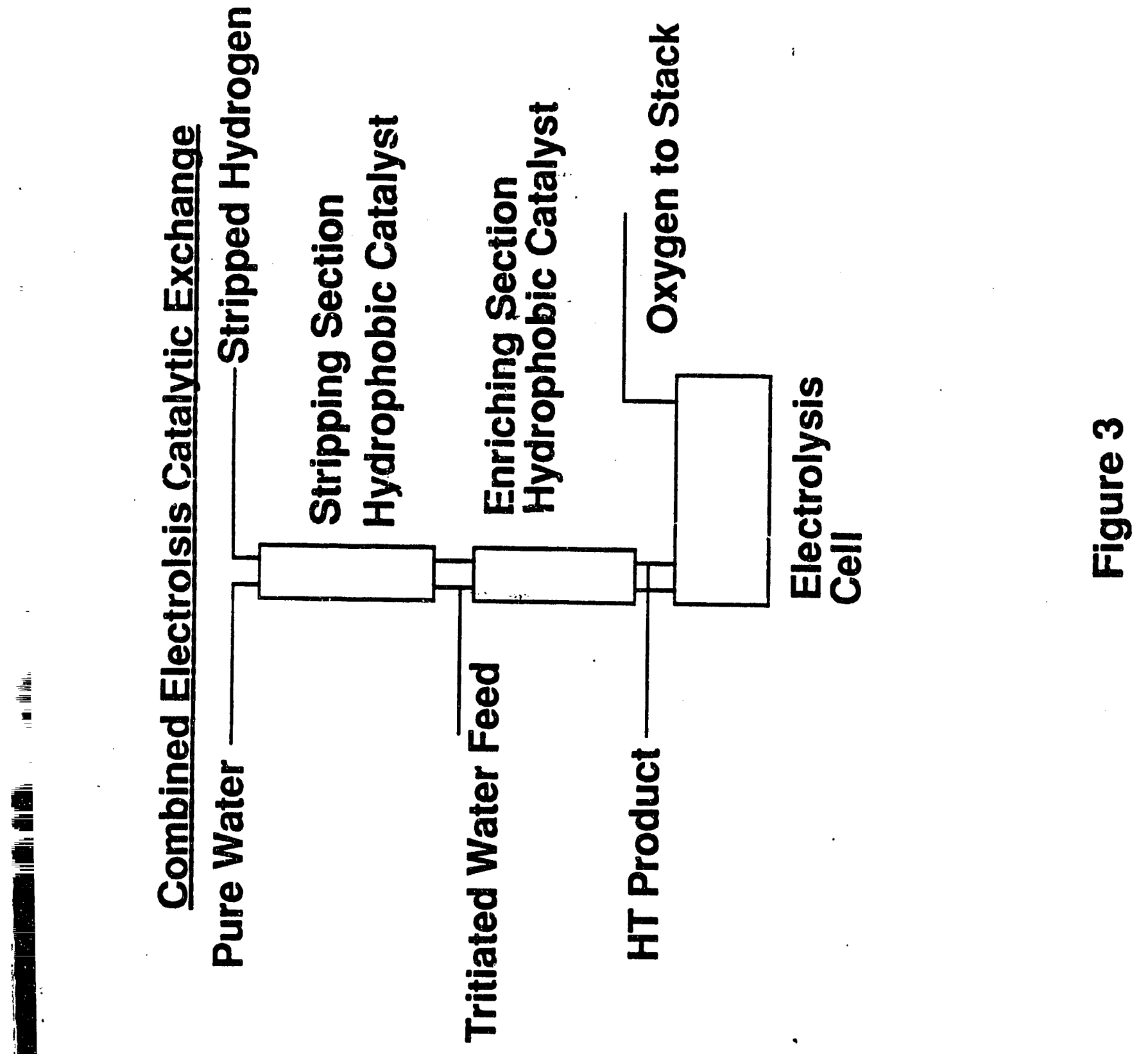



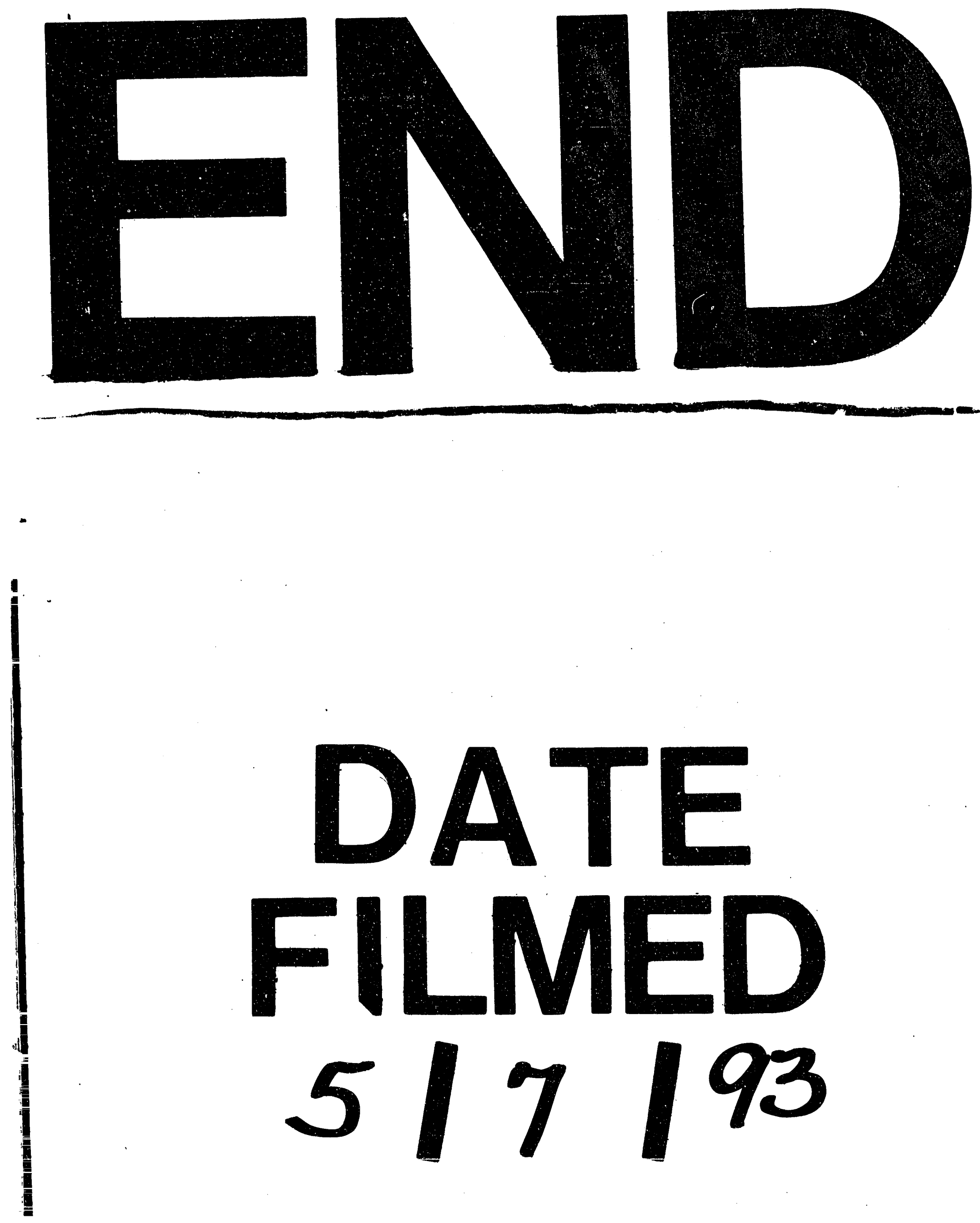


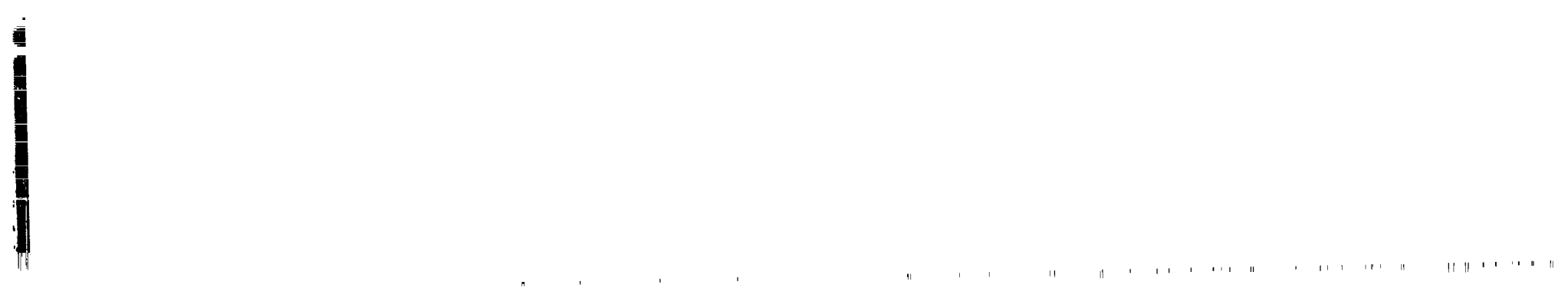

